\title{
Impact of Microfinance on Rural Household Poverty in Ethiopia:
} A Review

\author{
Nigusu Abera* \\ Salale University \\ Milkessa Asfaw \\ Mizan Tepi University
}

\begin{abstract}
Poverty is highly affecting the life's of the population of Less Developed Countries (LDCs) in general and that of rural people in particular. High vulnerability, lack of education and medical services, less participation in different decision-making activities are some of the major problems the rural people faced. To overcome these and other related socio-economic problems, micro finance Institutions (MFIs) targeted the poor in general and the rural people in particular. The main objective of this review is to find out whether the provision of microfinance services has brought changes on the living standards of clients. It is expected that microfinance services create employment opportunities, increasing income, enhancing empowerment and in aggregate improve the livelihood of the poor. Even though the performance of microfinance increase from time to time there are many problems facing microfinance institutions in Ethiopia. These includes inaccessibility for a foreign capital which may foster their loan portfolio, failure to repay loan at all or partly or not paying on time which causes serious problems on sustainability of the institutions, lack of research to understand client needs and lack of follow up of the clients. Reviewing the impact of microfinance intervention is important to know its viability on poverty reduction. The impact assessment of microfinance is conducted both at household and institutional outreach and sustainability. The impact of the program is assessed at household level based on average income, which in turn affects access to education, access to medical facilities, nutritional status, savings, employment generation and empowerment, among others, which are indicators of poverty. If outreach has been expanded and institution is sustainable, then the program is judged to have a positive impact as it has widened the financial market. Loan repayment performance is affected by a number of socioeconomic, institutional and natural factors, some of which are believed to impact on repayment negatively while others have positive impact. Major socioeconomic variables that affect credit repayment include education, age of household head, family size, gender of household head, farm size, loan size, livestock ownership, annual farm revenue, loan diversion, frequency of contact with development agent, group effect and location of borrowers from lending institution.
\end{abstract}

Keywords: Loan, Client, Impact, Poverty

DOI: $10.7176 / \mathrm{JESD} / 10-23-08$

Publication date: December $31^{\text {st }} 2019$

\section{INTRODUCTION}

Microfinance refers to the delivery of financial services such as credit, savings, insurance, etc. to clients who are without access to the services of formal sector financial institutions on sustainable basis (Moti, 2003). It gained a worldwide acceptance and popularity since 1980's. Micro-finance Institutions (MFIs) are often defined in terms of the following characteristics: targeting the poor (especially the poor women); promoting small businesses; building capacity of the poor; extending small loans without collaterals and combining credit with savings. Micro finance Institutions (MFIs) are one of the major policy instruments that highly play significant roles in poverty reduction activities particularly in enabling poor people to generate their income (Ejeta, 2006).

According to Tiruneh (2006) worldwide survey of 206 microfinance institutions that are opened in or before 1992 found that, only 7 percent had been in operation before 1960; and 48 percent had been founded between 1980 and 1989. Formally microfinance in Ethiopia started in 1994/5; particularly the licensing and supervision of microfinance institution proclamation of 40/1996 encouraged the spread of microfinance institution in both rural and urban areas. In addition to this, there are also different government policies, laws, and directives in Ethiopia, which affect directly or indirectly the development of the microfinance industry. These mainly include proclamation No. 83/1994, 84/1994, and 40/1996. Moreover, the seventeen directives issued by the National Bank of Ethiopia, constitute the major legal and regulatory framework which is used to regulate and supervise the microfinance industry (Ebisa Deribie*, 2013). According to Berrie (2015), Microfinance is considered a relatively new strategy to combat poverty. The delivery of micro finance services to the rural poor in Ethiopia is one of the effective instruments of promoting food production and food security (Kidane, 2003). The delivery of financial services has been viewed as one of the antipoverty tools of the development programs because of creating employment opportunities by increasing their income and consumption and then reducing poverty. Improving financial access to the poor also facilitates economic growth by easing liquidity constraints in production, by 
providing capital to start up new production. Therefore, the introduction of microfinance will have a significant effect in reducing poverty at macro and micro levels.

\subsection{Significance of the Review}

Identifying the impact of microfinance on living standard of the poor enables the microfinance institutions to explore which types of services are required by clients. This information is essential for all microfinance institutions to be demand responsive rather than supply driven in their choice of products and lending methodology. It is also important in providing insight for policy makers and microfinance institutions found at different levels in addressing the needs of the poor section of the people. Finally, it will be used as central and initial point for further research.

\subsection{Statement of the problem}

Microfinance institutions have been established and operating with the ultimate goal of poverty reduction. The majority of the poor access financial services through informal channels money lenders like: Iqub, Idir, friends, relatives and traders (Moti, 2003). Formal financial institutions are inefficient and inaccessible in providing credit facilities to the poor. The microfinance institutions functioning currently in the country exhibit a number of strengths in their operation. This include the service provision is centered on urban and rural poor particularly in alleviating the chronic problem of poverty, the number of clients served is growing from time to time making it accessible for the needy partners, regional distribution of the services is appreciable as microfinance institutions are operating in all regional states of the country.

Though the strengths of the micro financing industry outweigh its weaknesses, there are still big challenges facing the microfinance institutions. The first challenge is the inaccessibility for foreign capitals which may foster their loan portfolio. As a result, many MFIs are limited to certain category of services. Lack of skilled personnel is also the common problem in Ethiopian microfinance institutions. This situation is more exacerbated by high turnover of experienced personnel either for the need of better jobs or hate to work in rural areas with minimal facilities provided as compared to urban areas which offer better living conditions. There is also a problem of using modern core finance technologies for many of MFIs specially those microfinance institutions operating in remote rural areas having poor infrastructure development (Ebisa Deribie*, 2013). As a result, there are problems of non standardized reporting and performance monitoring system. Other challenges most commonly cited are lack of knowledge about microfinance services, weak governance and management capacities for further developments, low interest rates in the microfinance industry affecting the financial health and viability of MFIs, limited outreach particularly for women and failure to repay loan at all or partly or not paying on time which causes serious problems on sustainability of the institutions, lack of research to understand client needs (Tiruneh, 2006).

\section{Specific Objectives}

The specific objectives of this review were:

* To review the performance of microfinance institution in Ethiopia

* To review the impact of micro finance institution on the income of clients.

* To review the determinant of loan repayment performance of a client

\section{LITERATURE REVIEW}

\section{The emergence and performance of micro finance institution}

Micro credit started as government and non-government organizations motivated scheme. Following the 1984/85 severe drought and famine, many non-governmental organization (NGOs) star started to provide micro credit along with their relief activities although this was on a limited scale and not in a sustained manner. But these loans were not based on proper needs assessment and no mechanism was in place to monitor their effectiveness. In many cases, these loans were not to be repaid and might have foster a culture of not repaying loans (Yirsaw, 2008). The approach is known as poverty lending approach that is supply-driven rather than demand driven and focused mostly on credit. This approach disregarded the domestic saving mobilization. Moreover, the credit delivered by NGOs faced many problems which includes charging interest rates that do not reflect true costs, lack of sound lending and collection policies and procedures, credit was delivered without verifying borrower integrity and skill, lending based on NGO staff needs rather than felt needs of borrowers, loan terms were not based on repayment capacity, lack of collection efforts by the staff and providing loan outside the target group (to staff friends and relatives). In recent years, the informal sector has continued to assume increased prominence mainly due to restrictive rules and regulations of the formal financial sector. Informal sector transactions are conducted on the basis of trust and intimate knowledge of customers. Also, the fact that collateral is rarely used in the informal sector enables it to flexibly satisfy financial needs that cannot be met by the formal financial institutions. However, it does not generate enough and affordable finance for business to stimulate economic development.

Developing countries including Ethiopia the poorer section of the community did not get access to formal 
financial sectors. They were simply kept out of the reach of the formal financial institutions for several reasons. First, formal financial sectors require collateral and credit rationing. Second, they prefer for high-income clients and large loans. Third, the processes and procedures of providing loan are bureaucratic and lengthy. Fourth, they are often demand for loan by the poor as unattractive and unprofitable (Gebeyehu, 2002, Mulat et al, 1998 and Wolday, 2000, 2001 and 2002). On the other hand, informal financial sectors were not good either. They usually require high interest rates, which the poor cannot afford to pay. These situations have also found to restrict the access of the poor towards informal financial sectors. Thus, the limitations of financial institutions in providing the poor with credit have become the driving forces behind the emergence of MFIs. Micro finance is the process of lending small amount of money without collateral to help poor people to become entrepreneurs. In addition to this, it provides small scale financial services to the rural and urban poor people for self employment and small business. It is possible to argue that micro finance institutions are institutions that provide financial services to meet the need of low income sections of the population (Tafese, 2014).

Recently, financial sector has been increasing through both branch expansion and emergence of new private sectors. Since the takeover of the present government in 1991, considerable attempt has been made to liberalize the financial sector. To this effect, Proclamation No. 84/94 was issued, which allows private domestic investors to participate in banking and insurance activities, which were previously monopolized by the government. However, the issuance of this proclamation alone did not totally solve the financial problem of the economically active poor people in rural and urban areas (Seifu, 2002). Another Proclamation, No. 40/96 was issued to solve the problem of the delivery of financial services to the poor. Following the issuance of this proclamation the microfinance industry of Ethiopia showed a remarkable growth in terms of outreach and sustainability. Furthermore, the National Bank of Ethiopia issued a new directive on May 2002 to improve the regulation limits on loan size (Br. 5000), repayment period (one year), and lending methodology (social collateral). Microfinance institutions in Ethiopia are allowed to mobilize saving deposits from their clients and the public. Almost all microfinance institutions have a common objective: poverty reduction through provision of credit and saving services using group based lending methodology.

Microfinance institutions are emerging rapidly in the country based on the new approach and in line with the new microfinance law. According to the annual report of the national bank of Ethiopia (2012/13), the number of Microfinance Institutions (MFIs) operating in the country were 31. Of these, eleven Micro finance institutions (MFIs) (about 41\%) are located in Addis Ababa and thirteen MFIs (about 48\%) are located in Oromia region, with $21.1 \%$ and $18.2 \%$ of the shares in total capital of all the MFIs, respectively. Moreover, about $81.3 \%$ of total capital of all MFIs in the country are belonging to only four of them i.e Amhara (25.6\%), Dedebit (24.3\%), Addis (16.3\%) and Oromia (14.7\%). Within a region, the existing branches of MFIs have not fully covered all districts. The total amount of capital in MFIs in Ethiopia was amounted to $\$ 94.27$ million (1.2\% of GDP), of which $\$ 88.84$ million (1.1\% of GDP) was mobilized through saving and the rest from donors and shareholders, where as it extended a total credit of about $\$ 230.71$ million to about 1.5 million borrowers throughout the country. The performance of microfinance industry in Ethiopia appears impressive measured in terms of their rural presence, outreach of their services and repayment and sustainability. The achievement is not only in supplying financial services for the poor but also in realizing and strengthening lending and payback systems (financial system development that serves the poor) of the country. In spite of the encouraging development, millions of poor in Ethiopia suffer from lack of savings and limit access to working and investment capital to start income generating activities. The potential demand for credit in Ethiopia is high. For instance, at the households' level, 9 million poor households in Ethiopia need credit. This demand remains largely unmet with the existing capacity and structure of financial institutions in Ethiopia (Degefe, 2004).

Some MFIs in Ethiopia have not reached in their operational self- sufficiency and financial self- sufficiency. The average operational and financial self- sufficiency of microfinance institutions in Ethiopia is 104 percent and 77 percent compared to African MFIs 111.1 percent and 93.7 percent respectively (Tsegaye, 2005). Accordingly, their total capital and total asset increased by 20.8 and 33.0 percent and reached Birr 4.5 billion and Birr 17.7 billion, respectively. Deposit mobilization and credit provision activities of micro- finance institution have also witnessed a remarkable increment. Compared to last 2011/12, deposit mobilization went up by 39.6 percent and reached Birr 7.6 billion. Their credit provision capabilities also rose by 37.6 percent indicating the expanded outreach of the microfinance institutions.

The tools to measure the social performance of microfinance institutions such as outreach in number of clients served and depths (clients poverty level), financial structure, financial performance, efficiency and productivity, and portfolio quality (loan repayment) are found to be effective measurements in order to investigate the structure of institutions and their use for the community. The performance of microfinance institutions in breadth has its own sub measurements in terms of types of the financial service offered, number of branches established, percentage of loans to clients, percentage of female clients and targeted population served, range of financial and non- financial services, and level of transaction costs and extent of client satisfaction. Mostly the microfinance institution earns its income from loans and funds from other non-government organizations, penalty, and 
commission. In Ethiopia, the financial performance shows that it needs a long term prospect in order to develop. Most MFIs are able to operate without covering their costs due to subsidies and gifts from governments and other donors. Accordingly, Institutional sustainability was keys to successful provision of financial services to the poor and financial self-sufficiency was a necessary condition for institutional sustainability.

Governance of MFI is a system that links the shareholders to the board, the management, and the staff, clients, and the community at large. Sound governance is fundamental in creating efficient and sustainable micro finance institutions in Ethiopia. The major elements of sound governance are transparency, accountability, board members' dedication and commitment of members to the mission and activities of the institution, policies and procedures that the boards follow and skills of chairpersons (skills in leadership, vision in thinking and management). The ownership structure of MFIs includes regional government, local NGOs, and individuals.

\section{Situation of poverty in Ethiopia}

Many authors define poverty in different ways by considering different criteria and indicators of poverty. Some researchers have defined the poor as that portion of the population that is unable to meet the basic nutritional needs. Others viewed poverty as a function of education and/or health using the measurement of life expectancy, child mortality, etc. Level of expenditure and consumption are other criteria used to identify the poor (Berrie, 2015). Tiruneh (2006) defined the concept of poverty as a situation of poor health facilities, low level of education, malnutrition and lack of participation in decision-making process. Understanding poverty in the Ethiopian context also needs to consider its multidimensional characteristics which go beyond mere income and food provision. Such characteristic includes aspects of human capabilities, assets and activities necessary for sustainable livelihoods. A sustainable livelihood is one that can "cope with and recover from stresses and shocks and maintain or enhance its capabilities and assets both now and in the future, without undermining the natural resource base" (Enquobahrie, 2004). The fundamental bases of livelihood comprise natural (land, forests, water, pastures, and wild life), physical (farm animals, tools/machinery, economic and social infrastructure), financial capital (income and savings), social relations and human capital (health, education etc). The Ethiopian situation clearly reflects the degree to which the bases for sustainable livelihood are adversely affected by natural and man-made calamities. The underprivileged poor have limited access to most of the livelihood capital assets which has widened income disparity and undermined their bargaining power to establish sustainable livelihoods.

It is not easy to measure poverty like that of its definitions. Thus, measures of poverty are different in different countries. Conventionally, the income or expenditure level that can sustain a minimum standard of living measures it. Poverty can be commonly measured by constructing a line called poverty line. Poverty line is defined as a threshold level of per capita income or consumption level below which an individual is labeled to be poor (Tiruneh, 2006). People below this threshold is said to be poor. Poverty line can be estimated in two different approaches. These approaches are absolute poverty and relative poverty. Absolute poverty refers to a set standard which is the same in all countries and which does not change over time. Whereas, Relative poverty refers to a standard which is defined in terms of the society in which an individual lives and which therefore differs between countries and over time (Kitessa, 2012).

Poverty is multi-dimensional and has to be looked at through a variety of indicators such as levels of income and consumption, social indicators and indicators of vulnerability to risks and socio-political access and participation. The study of poverty also includes developing indicators to track other non- income dimension of poverty such as risk, vulnerability, social exclusion and access to social capital. The majority of people in Ethiopia are living in rural areas where poverty is more widespread than in urban areas. About 45 percent of the rural populations are below the nationally defined poverty line, while it is 37 percent for urban population. Poverty is also deeper and severer in rural areas than in urban areas. On average, the income of the rural poor is 12.1 percent far from the poverty line, while it is 10.1 percent for the urban poor (Tassew, 2004). Similarly MoFED (2002b) estimated the poverty incidence of 45.4 percent and 36.9 percent, depth of 12 percent and 10 percent, and severity of 4.6 percent and 3.9 percent for rural and urban Ethiopia respectively.

The proportion of people in Ethiopia who are absolutely poor (those whose total consumption expenditure was less than US\$124.28 per year) during the year 1999/00 was 44\% (MOFED, 2002). Poverty alleviation programs in Ethiopia, as in other developing countries, need to protect the poor from destitution, sharp fluctuations in income and social insecurity. Involving the poor in rural works, provision of food-subsidy and encouraging selfemployment can be the basic components of poverty alleviation efforts. Self employment of the poor can be induced through provision of productive assets and appropriate skills, subsidy and bank credit, supply of improved tools and other support services and provision of durable social and economic assets for sustained employment and development. Such efforts would require adequate funds, appropriate policy framework and effective delivery mechanism to make use of resources in cost-effective manner which, apparently, requires high degree of commitment, motivation, competence, integrity and adequate monitoring systems. 


\section{The impact of micro finance institution on the income of clients}

There are two major schools of thought that are prominent in impact assessment of microfinance. The first approach is the one, which focuses on the intended target groups or clients. This is the case that is developed by USAID's AIMS project that seeks to assess impact at household, enterprise, individual and community levels. At household level, impact is measured by increase in household income, asset accumulation and labor productivity i.e. income, assets and welfare (Tsehay and Mengistu, 2002). Income, expenditure, consumption and assets can be used as indicators of impact. At the enterprise level, five domains of development are: the resource base, production process management, markets and financial performance. At the individual level three domains of well being include: independent control of resources; leverage in household decision-making and community participation. At the community level four domains of development are: net change in employment and income forward and backward linkages, social networks and civic participation.

Household assets include radio, chairs, tables, benches; livestock's, plants and land. The welfare that was included in consideration is housing improvements, household nutrition, education and medical facilities. The choice of levels depends on the objective of the assessment and nature of the programme. The second approach purely focuses on changes on the organization and its operation. This approach focuses on institutional outreach and sustainability (Yaron, 1994). The assumption is that if both outreach and sustainability have been enhanced, then the intervention is judged to have a beneficial impact as it has widened the financial market. This, in turn, is based on the assumption that institutional impact extends the choices of people looking for credit and saving services and this extension of choice ultimately leads to improved micro enterprise performance and household food security (Tsehay and Mengistu, 2002; Moti 2003)

\section{Impact Assessment at Household Level}

At the household level, the impact of microfinance intervention is observed in association mainly with income, assets, and social empowerment of the frequent borrowers by comparing with the non-clients. In order to evaluate the impact of micro finance on poverty reduction, the methodology suggested by Fidler and Webster (1996), which is the evaluation of changes in user livelihoods as a result of micro financing scheme, is employed. i.e compares the livelihood of clients and non-clients. Assessing impact at the participant level requires adjustments to control for differences in unobservable household characteristics. The impact of the program is assessed at household level based on average income, which in turn affects access to education, access to medical facilities, nutritional status, savings, employment generation and empowerment, among others, which are indicators of poverty (Moti, 2003).

In spite of methodological difficulties involved in measuring the impact of credit, studies have demonstrated that the availability of credit can have positive effects on income. A study by the government, NGOs, and banks involved in providing financial services for poor household that had received credit were compared with households, which had not. The results demonstrated that credit provision could enable household incomes to rise (Susan and Rogaly, 1997). Another study by Getaneh (2001) reveals that the financial services has increased income and improved food security of clients. Access to finance in the rural area has improved access to education and health services. The clients reported that they were better off after obtaining the financial services. Generally, credit removes the financial constraint to production and helps to accelerate the adoption of new technologies, increase productivity, and improve national and personal incomes. In addition, it constitutes an integral part of the process of commercialization of the rural economy and a convenient means of addressing rural poverty (MoA, 1995).

Some Scholars argue that MF services have negative impacts on clients. Although micro-credit has claimed more and more of the aid budget, it may not always be the best way to help the poorest and the fervor for microcredit may siphon funds from other projects that might help the poor more. Sometimes even when repayment rates are higher, it may be painful to the clients making them pay from other sources such as sales of their limited assets. It increases indebtedness risks for poor people because it makes them remain trapped in the vicious circle of poverty. However, it does not mean that MF is worthless but the question is whether MF is better than some other development projects for the poor as whole. Moreover, provision of micro-credit can be one tool to reduce poverty but not the only one. There are at least four negative externalities that should be considered in MF development. These are, facilitating de-industrialization, facilitating trade deficits and import dependency, facilitating the destruction of social capital and facilitating one- dimensional response to poverty reduction and local economic development (Bateman, 2003).

Meehan (1999) in her study on the impact of credit provision by DESCI in Tigray region revealed that the majority of respondents ( 83 percent) reported that an initial increase in households' income due to credit services. The incremental income is mainly used for basic household food supply, clothing and education of children 80 percent, 60 percent and 40 percent respectively. The provision of credit in response to demand and the impact of credit access and usage has resulted in increasing household income and decreasing poverty levels in the study area is depend on continued access to credit. Asmelash (2003) indicated that the overall household income of frequent clients has increased than the overall household income of the new clients in both urban and rural areas 
in 12 months. The result suggested that DECSI has a positive impact on diversification of income sources for clients. The frequent borrowers have a better housing condition and increased asset ownership, improved ability to pay educational and medical expenses than non-participants. In the same token frequent borrowers have better diet improvement, job opportunity creation and participation in decision- making (empowerment) than the nonparticipants. Similar conclusion has made in micro-credit income diversification case study in central Tigray conducted by Tassew (2004). In general the findings revealed that microfinance intervention has a positive impact on the livelihoods of the households. Thus, it has an impact in poverty reduction. But the depth of impact is different in different countries and different MFIs because of several factors. Some of the factors can be size of the financial service provided, institutional performance, information availability, accessibility, infrastructure availability, awareness of the clients, approach or methodology, environment and others (Tiruneh, 2006). Another impact study on SFPI conducted by Jimbed consult P.L.C (2001) concluded that at the individual level personal income and savings have shown improvements. Additionally household income and welfare has been increased. It can be evidenced by the study that most of school- aged children are in school and there is an improvement in household diet as a result of the microfinance services of SFPI. The microfinance intervention has also an impact at the enterprise level by enterprise expansion, addition of new products, improving quality of products, improving management skills, and cost reduction.

\section{Outreach and loan repayment performance}

The outreach and sustainability of MFI approach is also another prominent tool to assess the impact of micro financing scheme on poverty alleviation. The assumption is that if outreach has been expanded and institution is sustainable, then the program is judged to have a positive impact as it has widened the financial market. This, in turn, based on the assumption that credit and saving services led to improve household security and economic status of the clients (Moti, 2003). Haileselassie's study (2005) on financial sustainability of microfinance institutions by taking a case study of SFPI and PEACE revealed that outreach, financial self-sustainability and institutional building are the main indicators of microfinance performance. His findings indicated that MFI's have achieved extensive outreach in providing financial services to the urban and rural poor. Saving mobilization was significantly increased and at the same time repayment rate was very high in both institutions (98 percent and 99.6 percent of SFPI and PEACE respectively). The trend of financial performance showed that there is a good and steady progress towards reaching operational self-sufficiency. But both institutions are still subsidized. It is possible to say that the performance of the institution affects the impact of the intervention in poverty reduction. Loan repayment capacity may show the positive or negative impact of the credit. The assumption is that if the clients used the loan for productive activities to generate income, they can pay their loan. Otherwise the credit may increase indebtness on clients. The survey result indicates that about $89 \%$ of clients repaid their loan early and in accordance with the schedule of the institution. Few clients (about 9.6\%) were unable to pay their loan according to the schedule. Urban clients had better repayment performance than rural clients, $98 \%$ for urban and $90 \%$ for rural. The survey results reveal that there is an attitudinal change of clients from considering microfinance institutions as charity organizations to finance service delivery institutions (Tiruneh, 2006).

\section{Determinant of loan repayment performance of clients}

Credit as the power or ability to obtain goods or services in exchange for a promise to pay for them later. In other words, it is the power or ability to obtain money, through the borrowing process, in return for a promise to repay the obligation in the future (Assefa, 2002). According to these authors, credit represents the actual or prospective debtor's power or ability to affect an exchange by offering his promise for future payment. Knowledge of determinants of loan repayment is undoubtedly important for it provides information to the lender on the incentives available for the borrower to comply with repayment schedules. Loan repayment performance is affected by a number of socioeconomic, institutional and natural factors, some of which are believed to impact on repayment negatively while others have positive impact (Berhanu, 2005). The factors affecting repayment performance of MFIs can be divided into four factors namely individual/borrowers factors, firm factors, loan factors and institutional/lender factors (Cherkos, 2014). The main factors from the lender side are high-frequency of collections, tight controls, and a good management of information system, loan officer incentives and good follow ups. In addition, the size and maturity of loan, interest rate charged by the lender and timing of loan disbursement have also an impact on the repayment rates. Several studies show that when a loan is not repaid, it may be a result of the borrowers' unwillingness and/or inability to repay. Major socioeconomic variables that affect credit repayment include education, age of household head, family size, gender of household head, etc. Family size is expected to affect loan repayment performance positively. This is because farmers with more families may have more labor force for more diversified sources of income. Educational level of household head is another socioeconomic variable that affects loan default rate both positively and negatively. According to Mengistu (1997) conducted a study on the Market Town Development Program (MTDP) Credit Scheme of Bahir Dar and Awassa towns using a multinomial probit model. The study indicated that education has positive impact on loan repayment. 
Bekele et al (2003), in his Ethiopian case study revealed that, even if the variable was statistically insignificant there was a negative relationship between educational status of household head and household's loan repayment performance. Logically as age increases the repayment capacity of borrowers is expected to increase. This is because through time farmers acquire experience and knowledge of credit uses. Moreover, older farmers are in a better position to accumulate wealth than younger ones. This logical expression was supported by Berhanu's (1999) result. According to him the age of a borrower has positive impact on full loan repayment.

Belay (2002) showed that farm size was important factor influencing the loan repayment performance of rural women in Eastern Ethiopia. The total farm size, which is a proxy for a host of factors including wealth and income, has a significant and positive impact on loan repayment performance. Livestock ownership is another socioeconomic variable that affects repayment performance. Belay (1998) in a case study at Alemegena District (Ethiopia) found out a significant positive relationship of livestock ownership and loan repayment performance of farmers. Accordingly, animal production was found to be important source of cash income during sharp fall of crop prices. Also, Bekele (2001) in his Ethiopian case study using logit model revealed that value of total livestock holding has positive impact on loan repayment performance of smallholder farmers. According to the study, farmers who owned more livestock were able to repay their loans.

Bekele (2001), in his Ethiopian case study, revealed that off-farm income influenced the loan recovery of farmers negatively. According to him, larger proportion of defaulter households participated in off-farm activities than the non-defaulters. Households who exercise off-farm activities probably gave less attention to farm affairs as income was generated from different angles. In other words, households who generate income from off- farm sources tend to be will full defaulters, because the punishment, which could be inhibition of access to credit in the following season, may be less painful to them as they are less dependent on farm activities. The other possible explanation is that households who take part on off-farm activities may divert input loans to supplement the offfarm business. Institutional variables were other factors, which could affect loan repayment performance of smallholder farmers. Possible institutional factor that affect loan repayment include extension contact, source of credit, loan amount etc. As far as source of credit is concerned, Miller (1997) indicated that the principal reasons for some loans not to be repaid are: borrowers anticipate a change in credit policies or because they lack confidence in the ability of credit institutions' to provide credit in the following year. Wenner (1995) stated that, formal lenders find difficult and costly to ascertain accurately the likelihood of defaults and monitor closely how borrowers use funds and what technologies they choose for project implementation. Thus, borrowers may not take actions that make repayment more likely (moral hazard). Weak legal system, lack of secured collateral, and pervasive views that government bank loans are patronage magnify loan enforcement costs for formal loans. In contrast, informal lender faces substantially lower screening and monitoring costs because of social proximity and multi- stranded relationships with clients. Thus, credit obtained from informal sources has high likelihood of being repaid than credit obtained from formal sources.

Bekele et al. (2003) in a case study of Ethiopia using logit model, stating that farmers who took larger loans had better loan repayment performance. According to them, this could be attributable to the effectiveness of local leaders in screening loan applications. The results of Belay (1998) also strengthen the finding of negative relationship between loan default and loan amount. Berhanu (1999) also reported that loan size contributed to reduction of the probability of full loan repayment in Ethiopia. Different researchers emphasized the influence of the frequency of farmer's contact with development agents on loan repayment performance. Logically, the higher the linkage between farmers and development agents, the more the information flow and the technological (knowledge) transfer from the later to the former. Therefore, the farmers who have frequent contacts with development agents are likely to settle their debt timely as opposed to those who have no or less contacts. Belay (1998) reported that, those farmers who made frequent contact with development agents were those who paid their loans back to the lenders in time where as those who had less or no contact were defaulters. According to Assefa (2002) Out of the twelve variables hypothesized to influence the loan repayment performance of borrowers, six variables were found to be statistically significant. Some of these variables are farm size, annual farm revenue, celebration of social ceremonies, loan diversion, group effect and location of borrowers from lending institution.

\section{CONCLUSION}

The government of Ethiopia believes that microfinance institutions are one of the instruments in poverty reduction. It is expected that microfinance services create employment opportunities, increasing income, enhancing empowerment and in aggregate improve the livelihood of the poor. Accordingly, Proclamation No. 40/1996 was established in 1996 to promote microfinance development in Ethiopia. Following this, many (thirty one) microfinance institutions have been emerging in remarkable manner in Ethiopia. Microfinance institutions are decisive way outs from the vicious circle of poverty particularly for the rural and urban poor segment of the society especially in a country like Ethiopia where many people live barely below the absolute poverty line.

The primary objective of microfinance (MFIs) is to provide financial services (credit and saving) to the poor in order to relieve financial constraints and help alleviate poverty. Each MFI tries to maximize its repayment 
performance, whether it is profit oriented or not. One indicator of effective MFIs is the loan repayment performance of the borrowers. High repayment rates are associated with benefits both for the MFI and the borrowers. If there is high repayment rate, the relationship between the MFI and their client will be good. High repayment rate helps to obtain the next higher amount of loan and other financial services. In contrast, if there is low repayment rate, both the borrowers and the MFI will be affected. In this case the borrowers will not be able to obtain the next higher loan and the lender will also lose their clients. Improving repayment rates helps reduce the dependency of the MFIs on subsidies, which would improve sustainability. It is also argued that high repayment rates reflect the adequacy of MFIs' services to clients' needs. In order to maintain sustainability of MFIs, one important thing is to identify the socio-economic and institutional factors which significantly affect the performance of loan repayment rates from different perspective. There are many socio-economic and institutional factors influencing loan repayment rates in the MFIs. The main factors from the lender side are high-frequency of collections, tight controls, and a good management of information system, loan officer incentives and good follow ups. In addition, the size and maturity of loan, interest rate charged by the lender and timing of loan disbursement have also an impact on the repayment rates. The main factors from the borrower side include socio-economic characteristics such as, gender, educational level, marital status and household income level and peer pressure in group based schemes. Most MFIs in Ethiopia are experiencing default problems as can be observed from their declining repayment rates. When one goes through the bulk of literature on the impact of microfinance, one can find quite different results, which are generally inconclusive. In some cases, microfinance is said to have brought positive impacts on the life of the clients. A growing database of empirical studies shows that microfinance has positive impacts to boost the ability of poor people to improve the conditions in which they live. Research works indicate that the poor have taken advantage of increased earnings to improve consumption levels, send their children to school, and build assets. In some other instances, microfinance is said to play insignificant role towards mitigating the problem of the poor. But looking at the positive impacts, several studies indicate that microfinance allows poor people to increase their incomes by starting new enterprises or expanding existing ones. The argument is that through diversified sources of income, the people could be able to shield themselves against external shocks. Savings and micro insurance services could also allow poor individuals to plan for future expenses, cope with stochastic crises and cover unanticipated expenses.

\section{Conflict of interests}

The authors declare no conflict of interest.

\section{REFERENCES}

Abebe Belay (2002). Factors Influencing Loan Repayment of Rural women in Eastern Ethiopia: The Case of Dire Dawa Area. Thesis Presented to school of Graduate Studies of Alemaya University.

Asmelash (2003). The Impact of Microfinance in Ethiopia: The case of DECSI in Ganta- Afeshum Woreda of Eastern Tigray. Master Thesis, Addis Ababa University: Addis Ababa, Ethiopia.

Bateman M. (2003). new wave Microfinance Institutions in South-East Europe: Small Enterprise Development. An International Journal of Microfinance and Business Development in Tawney C. (ed), Vol.14, No.3: ITDG Publishing, London.

Belay Kebede (1998). Agricultural Credit and Factors Impeding Loan Repayment Performance of Small-holders in Central Highlands of Ethiopia: The Case of Alemgena District. M.Sc. Thesis, Alemaya University of Agriculture, Ethiopia.

Berhanu Amare, (2005). Determinants of formal source of credit loan repayment performance of smallholder farmers: The case of north western Ethiopia, north Gondar.

Berhanu Lakew (1999). Micro enterprise Credit and Poverty Alleviation in Ethiopia. The Case of the Project Office for the Creation of Small Scale Business Opportunities in Addis Ababa. MSc. Thesis, Department of Economics, Addis Ababa University, Ethiopia

Berrie Mulugeta (2015). The contribution of credit and saving institutions in alleviating urban poverty: The case of addis credit and saving institution in yeka sub city. A thesis submitted to College of business and economics departement of public adminisration and development management.

Cherkos Sileshi (2014). Loan repayment performance of farm households: The case of omo microfinance in soddo zuria district of southern Ethiopia. A Thesis Submitted to the School of Agricultural Economics and Agribusiness, School of Graduate Studies, Haramaya University.

Degefe (2004) . Trends in Financial Development of Nine Microfinance Institutions from 1999 to. The Paper Presented in the Second International Workshop of RLDS, Addis Ababa University: Addis Ababa, Ethiopia.

Deribie Ebisa, Nigussie, Getachew and Mitiku Fikadu (2013). "Filling the breach: Microfinance". Journal of Business and Economic Management. Vol. 1. No.1. Available at http://www.academiapublishing.org/jbem

Ejeta Calchisa (2006). Impacts of micro finance on the livelihood of households particularly women:The case of Adea Liben woreda. A thesis submitted to the School of Graduate Studies of Addis Ababa University in 
partial fulfillment for the requirements of the Degrees of Masters Arts in Regional and Local Development Studies.

Enquobahrie, A. (2004). Understanding Poverty: A Paper presented at The Gambia AAPAM Roundtable Conference, Banjul, The Gambia, April 19 - 23, 2004 )

Fidler, Peter and Webster Leila (1996) "The Informal Sector and Microfinance Institutions in West Africa." World Bank Regional and Sectoral Studies. World Bank, Washington D .C.

Gebeyehu Tebeje (2002) "A Challenge to Institutional Sustainability" in Gebrehiwot Ageba (Ed). MF Development in Ethiopia: Prospects, Sustainability and Challenges on Poverty Reduction, Proceedings of the Conference on MFD in Ethiopia, Adama (Nazareth) Ethiopia: AEMFI.

Getaneh Gobeze, (2001) "Challenges of Microfinance as Anti-Poverty Strategy: Experience from ACSI."A Paper Submitted on the International Workshop on Dimension of Micro finance Institution in Sub-Saharan Africa: Relevance of International Experience. Meklle University Mekelle

Haileselassie T. (2005) . Financial Sustainability of Microfinance Institutions: A case study of SFPI and PEACE in Gebrehiot A. (ed), AEMFI: Addis Ababa, Ethiopia.

Jimbed Consult PLC. (2001) Assessment of Impact of the Credit Operation of SFPI on its Target Clients. SFPI: Addis Ababa, Ethiopia.

Johnson, Susan and Rogaly (1997) "Microfinance and Poverty Reduction”. Oxfam.

Kidane Anbes (2003). Pattern of credit use and its impact on small farmers income : A Study in Dire Dawa Area , Eastern Ethiopia.

Ledgerwood, Joanna (1999) Microfinance Handbook. An Institutional and Financial Perspective. The World Bank, Washington D.C., USA.

Meehan F. (1999) Microfinance in Rural Development: The Impact of Credit Provision by the Dedebit Savings and Credit Institution on Economic Activity and Household Income in Tigray M.Sc. Thesis: Ethiopia.

Mengistu Bediye (1997). Determinants of Micro-enterprise Loan Repayment and Efficiency of Screening Mechanism in Urban Ethiopia: The case of Bahir Dar and Awassa Towns, Addis Ababa.

Ministry of Agriculture (1995). Agricultural Credit Policies. National Agricultural Workshop. Addis Ababa, Ethiopia

MoFED (2002) Poverty Profile of Ethiopia: Analysis and Comparison of Poverty. Government of the Federal democratic Republic of Ethiopia: Addis Ababa, Ethiopia.

Moti Daba (2003) The Impact of Microfinance on Poverty Reduction: A Case Study of Oromia Credit and Saving Share Company. A Paper Presented in the International Conference on Microfinance Development in Ethiopia: Awassa, Ethiopia.

Mulat Demeke, V. Kelly, T.S Jayne, Ali Said, J.C Le Vallee and H. Chen (1998). Grain Marketing Research Project. Ministry of Economic Development and Cooperation. Addis Ababa.

National Bank of Ethiopia (2012/2013). Annual Reports. Addis Ababa, Ethiopia.

Seifu. A (2002). The Demand for Micro Credit Services in the Afar National Regional State. The Case of Gewane Woreda. MSC. Thesis, Department of RLDS, AAU

Tafese, G. S. (2014). The Role of Microfinance Institutions in Poverty Reduction and Women Empowerment in Ethiopia: The Case of Dedibit Credit and Saving Institution, 4(16),

Tasew Woldehanna (2004) New Pro-poor Policies, Pre- PRSP Experiences, and the 2003/04 Budget in Relation to Agricultural Food Security in Ethiopia, Addis Ababa University.

Teferi Zewdu (2000) Microfinance and the Poor. The case of Dedebit Credit and Saving Institution in Tigray. MSc. Thesis, Department of Economics, Addis Ababa University.

Tiruneh Abebe (2006). Impact of microfinance on poverty reduction in Ethiopia: unpublished. The cases of three branches of Specialized Financial and Promotional Institution (SFPI)

Tsegaye A. (2005) Ethiopian Microfinance Institution's Performance Analysis Report. Bulletin 1, AEMFI: Addis Ababa, Ethiopia.

Tsehay Tsegaye and Mengistu Bedye (2002) "The Impact of Microfinance services among poor woman in Ethiopia.” AEMFI Occasional paper No. 6 Addis Ababa, Ethiopia.

Wenner, Mark D. (1995). Group credit: A Means to Improve Information Transfer and Loan Repayment Performance. Journal of Development Studies. 32(2): 263-281.

Wolday A. (2000) Networking Microfinance Activities in Ethiopia: Challenges and Prospects. AEMFI Proceeding of the Conference on Microfinance Development in Ethiopia: Bahirdar.

Yaron, Jacob (1994) “Successful Rural Finance Institutions,” World Bank Discussion Paper No. 150, World Bank, Washington D.C. USA

Yirsaw, A. (2008). The performance of Micro Finance Institutions in Ethiopia: A case of six microfinance institutions Research Paper Submitted To Addis Ababa University In Partial Msc . Program In Accounting And Finance. 


\begin{tabular}{|c|c|c|c|}
\hline No. & Microfinance Institutions & $\begin{array}{l}\text { No. of borrowing } \\
\text { clients }\end{array}$ & $\begin{array}{l}\text { Amount of loans provided } \\
\text { (Birr }\end{array}$ \\
\hline 1 & Amhara Credit and Saving Inst (ACSI) & 694,993 & $1,940,827,401$ \\
\hline 2 & Dedebit Credit and Savings Inst (DECSI) & 396,648 & $1,849,942,011$ \\
\hline 3 & Oromia credit and saving institutions & 503,000 & $1,280,000,000$ \\
\hline 4 & Addis credit and saving institutions & 156,148 & $566,826,000$ \\
\hline 5 & Aggar Microfinance & 17,359 & $14,974,452$ \\
\hline 6 & Benishangul Gumuz Microfinance & 5,854 & $19,130,224$ \\
\hline 7 & Buusaa Gonofaa Microfinance & 28,874 & $51,762,087$ \\
\hline 8 & Digaf Microfinance & 48,908 & $76,548,872$ \\
\hline 9 & Diredawa Microfinance & 1,270 & $1,334,920$ \\
\hline 10 & Dynamic Microfinance Inst & 5,923 & $16,285,631$ \\
\hline 11 & Eshet Microfinance & 261 & $2,224,932$ \\
\hline 12 & Gambela Microfinance & 24,116 & $40,588,029$ \\
\hline 13 & Gasha Microfinance & 880 & $1,173,831$ \\
\hline 14 & Ghion Microfinance & 6,991 & $14,736,312$ \\
\hline 15 & Harar Microfinance & 233 & 286,268 \\
\hline 16 & Harbu Microfinance & 2,706 & $7,101,769$ \\
\hline 17 & Lefayeda Credit and Savings & 17,984 & $23,808,751$ \\
\hline 18 & Letta Microfinance & 303 & 623,441 \\
\hline 19 & Meket Microfinance & 925 & $4,790,020$ \\
\hline 20 & Meklit Microfinance & 2,959 & $2,329,562$ \\
\hline 21 & Metemamen Microfinance & 14,224 & $23,029,053$ \\
\hline 22 & OMO Microfinance & 10,218 & $8,720,938$ \\
\hline 23 & PEACE Microfinance Inst & 327,888 & $585,102,740$ \\
\hline 24 & Shashimene eddir yelimat Agar (SEYAMFI) & 17,206 & $45,507,171$ \\
\hline 25 & Sidama Microfinance & 4,144 & $10,959,365$ \\
\hline 26 & Specialized Financial \& Promotional Inst (SFPI) & 47,810 & $28,334,552$ \\
\hline 27 & Somali Microfinance & 33,342 & $50,807,161$ \\
\hline 28 & Tesfa Microfinance & 162 & 203,576 \\
\hline 29 & Wisdom Microfinance & 53,981 & $113,970,892$ \\
\hline 30 & Wasasa Microfinance & 45,331 & $101,205,955$ \\
\hline 31 & & & \\
\hline \multicolumn{2}{|c|}{ Total } & $2,470,641$ & $6,883,135,916$ \\
\hline
\end{tabular}

Source: (Cherkos, 2014)

Appendix 2. Ownership structure of microfinance institutions in Ethiopia.

\begin{tabular}{|l|c|l|l|}
\hline Micro finance institution & $\begin{array}{l}\text { Regional } \\
\text { government(\%) }\end{array}$ & $\begin{array}{l}\text { Association and } \\
\text { NGO(\%) }\end{array}$ & Individuals(\%) \\
\hline Amhara credit and saving institutions & 25 & 75 & - \\
Dedebit credit and saving institutions & 25 & 75 & - \\
Oromia credit and saving institutions & 25 & 70 & 5 \\
Omo micro finance institutions S.C & 80 & 19.5 & 0.5 \\
Addis credit and saving institutions & 96.7 & 3.3 & - \\
Dire micro finance institutions S.C & 97 & 2.5 & 0.5 \\
Benishangul micro finance institutions S.C & 40 & 60 & - \\
Harar micro finance institutions S.C & 96.6 & 3.3 & 0.1 \\
\hline
\end{tabular}

Source: National bank of Ethiopia (2011) 